\title{
THEOLOGICAL ANTHROPOLOGY AND GENDER RELATIONS
}

\author{
Nico Koopman \\ Department of Systematic and Ecclesiology Theology \\ Stellenbosch University
}

\begin{abstract}
In this article an anthropology characterized by vulnerability, relationality and dependence is offered as a pathway towards building male and female relations that are characterized by harmony and joy. This anthropology is in contradiction to the modernistic anthropology of power, autonomy and independence. The proposed anthropology is based in the doctrine of the economic trinity. This anthropology and the consequent joyous gender relations are actualized in Christian communities that do not live with practical atheism but that take the triune God seriously.
\end{abstract}

\section{Introduction}

In a chapter entitled "Feminist Theology For Men" in his book Experiences in Theology: Ways and Forms of Christian Theology, the famous German theologian Jürgen Moltmann, invites men to develop a male (2000:269) or masculine liberation theology (2000:271). This theology has to free both men and women from the estrangements brought about by patriarchal traditions (2000:271).

A significant number of feminist theologians, however, support the idea of men doing feminist theology. Letty Russell's definition of feminism, for instance, ${ }^{1}$ paves the way for men to do feminist theology. Feminism is an advocacy word. It advocates for the liberation of women. It does not do something against men. It does something for the needs of women. Feminist theology, according to Russell (1993:22), "represents a search for liberation from all forms of dehumanization on the part of those who advocate full human personhood for all of every race, class, sex, sexual orientation, ability and age." This definition forms the background for her conviction, and those of others, that men can do feminist theology if they advocate for, what I would like to call, the rehumanization of women. "Feminists are not necessarily biologically female and do not exhibit any particular genderstereotyped form of behavior that we usually call 'feminine"" (Russell 1993:22). The famous African women theologian Mercy Amba Oduyoye is also of the opinion that both women and men should be apostles of feminist theology. Feminism aims at the liberation of both females and males. "...even when we do not feel oppressed as a result of race and class and do not feel exploited, we may still not be living our full potential as human beings simply because we were born female or male as the case may be" (Oduyoye 1982:194).

Various factors seem to count in favour of Moltmann's proposal for a masculine liberation theology. The agenda that Moltmann sets for a male liberation theology, namely the overcoming of estrangements between women and men due to patriarchy, paves the way for serious attention to his invitation. His motivation for such a theology is also convincing. Such a theology may help men to recognize that sexism is not only a female problem. Here

1. In her famous work, The Skeptical Feminist, Janet Radcliffe Richards describes feminism as a movement that recognizes the fact that women suffer from systematic social injustice because of their sex. Feminism, therefore, is a movement for the elimination of sex-based injustice (quoted in Stott 1990:256). This definition implies that male and female are to be involved in the struggle to cleanse us all from sex-based injustice. 
one can add that men have to recognize and accept sexism as a female and a male problem just as white people have to recognize that racism is not only a black problem and just as wealthy people should recognize that classism is not only a problem of poor people. A masculine liberation theology therefore might help to serve the aim of drawing hitherto apathetic men to discourses on the liberation of both males and females.

Moltmann's arguments in favour of particularistic liberation theologies like black theology, Latin American liberation theology and feminist theology might serve as rationale for developing a masculine liberation theology. His rationale for these other liberation theologies firstly entails the separation of a liberation theology from the dominant traditional male theology. Secondly, such a theology needs to develop its own identity in order for it to address its specific concerns undisturbed and in freedom. Only when the envisaged liberation has been achieved can attention be given to the reciprocal development of a new common theology ${ }^{2}$ (Moltmann 2000:268-269). In the same vein Oduyoye argues that although particularistic theologies are sectarian in terms of their credenda (creeds and ideologies) and agenda (concrete tasks and action that flow from the credenda), they all contribute something to theological anthropology, that is, to "our search for a wholesome and meaningful way of being human as well as in the elaboration of what human being is all about" (Oduyoye 1982:193).

Despite these arguments, I am not yet convinced that the construction of a masculine liberation theology is the desired way to go. ${ }^{3}$ If you do need to give a name to the specific theology that strives for both the liberation of males and females, feminist theology would get my vote. My reason for this choice is the fact that women are more subjugated than males. In favour of this Oduyoye would add, "that the 'female' principle and perspective have not been explored sufficiently while the 'male' has been over-used to the point of staleness and stagnation thus plunging us all into a status quo that defies analysis" (1982:194). Maybe Moltmann's own motivation for white people doing black theology supports the appeal to men to do feminist theology. In a chapter in an above-cited book, entitled "Black theology for whites", Moltmann (2000:215) argues as follows:

If we listen seriously to the stories of the blacks, if we try to understand black theology, we begin to see ourselves and our own history through the eyes of the people who have suffered and are still suffering under our culture and our church. The person who has incurred guilt can no doubt admit his guilt, but only his victims know what suffering his injustice has caused. So we only become free of our own blindness if we see ourselves through the eyes of our victims and identify with them, because it was with them that the Son of man already identified himself (Matthew 25). White Christians should not, one day, have to ask unsuspectingly, 'Lord, when did we see you black?

2. In an article titled “'Becoming Male': One Aspect of an Early Christian Anthropology,” Kari Vogt hopes for the dawning of the time when the quest to be conformed to the image of God and Christ will not be spelled out as a process of becoming male, or becoming the perfect man. She hopes it will be portrayed as a process through which male and female become conformed to God, moreover as a process in which sex is transcended (1985:80).

3. Almost three decades ago the North American scholar, David Dvorkin, opposed the idea of a separate liberation movement for men. According to him such a movement would imply that men's liberation differs from women's liberation. Moreover, such a sex-based differentiation would ironically affirm the sexual typing from which liberation is sought (Dvorkin 1976:190). I do, however, disagree with the assumption in this argument that the recognition of sex differences necessarily implies the condoning of sexual stereotyping and prejudice. Liberation is not possible without recognizing differences. Such a recognition of differences also does not necessarily imply that men's and women's liberation differ. Better reasons for opposing such a separate male liberation movement, specifically in theology, can be offered. 
My suggestion is therefore that we men do not need to develop a masculine theology, but that we should become teachable and should do theology in a humble way. That means that we have to learn to listen to and follow the voices of women. Men can only participate in the liberation of women, and in their own liberation, if we identify with those who suffer under us and if we allow them to continually steer the discourse. Only in this way can we make a fruitful theological contribution. ${ }^{4}$

Despite such doubts about Moltmann's proposal for the development of a masculine liberation theology, his proposed agenda for such a theology deserves serious attention. In this paper I respond to the agenda of Moltmann's challenge. Oduyoye signals a way in which this challenge can be addressed. She rightly portrays sexism as an anthropological problem. Sexism in patriarchal societies refers to attempts to define humanity in terms of males only. Sexism is the refusal to incorporate women into the community of interpretation of what it means to be human (Oduyoye 1982:193). Sexism according to her can therefore only be overcome if females and males become conscious of, "the true nature of the human community as a mixture of those things, values, roles, temperaments, etc. that we dichotomise into feminine and masculine" (Oduyoye 1982:193-194) and if the assumption is done away with, "that the concept of maleness encompasses the whole of human being" (Oduyoye 1982:194). I am of the opinion that the exclusion of women from defining and determining what it means to be human makes all of us, female and male, losers. The concern is not only that the humanity of women is ignored because of this denial. Men are also dehumanized since they miss the opportunity to understand and experience full humanity.

In the same vein I propose that Moltmann's agenda that aims to liberate both female and male can be addressed by focusing on sexism as an anthropological problem. I specifically propose that a theological anthropology of relationship, dependence and vulnerability could provide an instrument for developing an adequate theological response to Moltmann's challenge. This understanding of God and of human beings in terms of interrelatedness, dependence and vulnerability does not necessarily constitute the building blocks of a masculine liberation theology, but it could help to advance the agenda of liberation from sexism that Moltmann sets for such a theology.

In the next section of this paper I outline the argument that a theological anthropology of independence, autonomy and power lies at the heart of the patriarchal traditions that caused the dehumanization of both males and females.

\section{A Theological Anthropology of Independence and Power}

a. The nature and consequences of patriarchy has in recent years been outlined in several publications. The English theologian John Stott gives an illuminating description of the nature of patriarchy and specifically of its portrayal of women in various cultures and ages. ${ }^{5}$ Plato, according to Stott, stated that a bad man's fate would be reincarnation as a woman. Aristotle viewed women as imperfect, mutilated males. The Jewish writer Josephus described women as inferior to men in every way. There is a well-known

4. Vogt's observes that the return to paradise was described in the long history of female hagiography as a process of women becoming men. Even fifth century monastic literature refers to the promotion of women to the state of men in certain conditions and milieus, as the link that binds doctrine, symbolic language and social reality together (Vogt's 1985:80). This reality should not inhibit us men from the quest to identify with women in the way it is pleaded for in this paper.

5. Moltmann (2000:278) mentions that it was only in the so-called pre-historic times that this patriarchal prejudice against women did not exist. 
Jewish morning prayer in which a man thanks God that he was not created as a gentile, slave or woman, affirms this low view of women. In the history of the church theologians at times also spoke disparagingly about women. Stott (1990: 255) quotes Tertullian as an example: "You are the devil's gateway; you are the unsealer of that (forbidden) tree; you are the first deserter of the divine law; you are she who persuaded him whom the devil was not valiant enough to attack. You destroyed so easily God's image, man. On account of your desert - that is death - even the Son of God had to die." Moltmann (2000:274) indicates how this subjugation exists in other cultures. Patriarchy reigned supreme in pre-Columbian cultures. In Chinese culture the woman has to serve three men throughout her life span: first her father, then her husband and lastly her oldest son.

Oduyoye offers a brief but insightful description of the affects of patriarchy on women in Africa. She states that the predominant view of women in Africa is that they are persons first and foremost in relation to whose mother or whose wife they are. She refers to the research of Christiana Oppong among Nigerian female university students, which offered the finding that these young women view themselves as men view them, namely the possession of the men who support them (Oduyoye 1982:194). Oduyoye (1982:195) also refers to various cults and practices that African women are not allowed to participate in. Although women can also participate in economic life, the work and products of women are viewed as inferior (Oduyoye 1982:196). Since the modernization and technologisation of women's work is viewed with suspicion, "African women still grind and pound their hours away" (Oduyoye 1982:196).

Moltmann (2000: 278) exposes the more visible and cruel consequences and manifestations of the age-old prejudice against women, amongst others the genital mutilation of two million women per annum in Africa. Currently 130 million women worldwide suffer under it.

The South African philosopher, Louise du Toit ( 2003:36-66) highlights rape as one of the most dehumanizing consequences of patriarchy. She describes the rape of women by men as first and foremost an assertion of power through an act of supreme humiliation. Du Toit (2003:54) states that this act of dehumanization is often committed in the presence of onlookers or spectators. The sexual pain and humiliation involved in the act of rape serves to affirm manhood and to demonstrate masculine power.

b. This brief description of the nature and consequences of patriarchy suggests that an anthropology of independence and power underlies patriarchy. This is also reflected in Moltmann's definition of patriarchy as, "the term for an institutionalized system of sexual hierarchy and a psychological mechanism for its justification, according to which the man is born and made to rule, while the woman is born and made to serve" (Moltmann 2000:274).

The anthropology of independence and power is also reflected in the British sociologist, Anthony Giddens' portrayal of the roots of the problem between males and females. He explains how males are unable to deal with the changing roles and identities of women. His argument broadly goes like this: During the industrialization era males had to go out to the industries to work. Women had the responsibility to keep the home and to raise the children. They consequently were dependent on males for material survival. Simultaneously they could acquire the skills to deal with intimacy since they had to care for the children. Women later could enter the job market. Soon they were not financially dependent on men anymore. They, however, still needed them in order to have children. In the light of technological development the situation of 
women has changed again. They could now have sexual relations without the risk and fear of falling pregnant. They can therefore engage in short term relations for the sake of enjoyment and not for the sake of financial protection and without the fear for unwanted pregnancies and sexually transmitted diseases. Moreover, they are now no longer dependent on relationships with men to get children. They do need the sperm of men to fall pregnant (as long as cloning of human beings is still in an infantile stage!), but they do not need men themselves, and definitely not relationships with them in which they are humiliated and subjugated. If they do choose to enter into relationship with men, it is not because they need them financially, nor for procreation.

Men who were raised to believe in their superiority and independence, and in women's inferiority and dependence, find it hard to redefine their new role and identity in this changed context. ${ }^{6}$ They struggle to deal with the newly found independence of women. ${ }^{7}$ And they struggle to express their love in other ways than in providing through hard work, firm discipline and low or non-existing levels of affection. ${ }^{8}$ This confusion and disorientation amongst men is one of the major causes of the conflict and disastrous relations between males and females (Giddens 2000). ${ }^{9}$

It is not difficult to see that an anthropology of rationality (work hard, use your cognitive abilities, do not show much emotion and affection; these are signs of weakness that women are allowed to express), independence and power (you are the strong one, she and the children need you, they are dependent upon you) underlies this picture of, shall I say, manhood and womanhood. Even ugly forms of the subjugation of women such as rape betrays the idea that they are inferior, of lesser worth, and that they are there for the commodification and consumption of the superior beings, namely men. I would even endeavor to say that underlying the genital mutilation of women is not cultural or religious motives, but these anthropological notions of independence, rationality, power and superiority. Culture and religion only affirm and sanction this anthropology.

c. The above-portrayed anthropology of power and autonomy is supported by various religious and nonreligious traditions, amongst others the western branch of Christianity

6. In a newspaper article the middle-aged South African artist, Koos Kombuis (2003:18), blames the anthropology of independence and power for the disorientation regarding masculine identity that men experience and also for the low level of trust that they enjoy amongst women. "Maar dit is bo alles die mans van my en die vorige generasie wat my my eie kop in skaamte wil laat sak. Die oorlogbeluste, ambisieuse, ongevoelige mans wat die wêreld binne 'n paar dekades in twee globale en talle kleiner oorloë gedompel het en die ekologie haas onherstelbare skade berokken het, die jagse, gevoellose, selfbehepte staatsmanne en leiers wat die aardbol beskou as hul speelgrond waar hulle al die onbehoorlike en onvanpaste fantasieë kan uitleef wat hulle in hulle ronddra omdat hulle self as kinders nie genoeg cowboys en kroeks gespeel het in die sandput nie. Vir ouens soos ek, wat baie graag die balans wil herstel, is daar geen duidelike riglyne nie. Dit help nie om vir vroumense te verduidelik jy glo in feminisme nie; hulle dink jy lieg of jy's 'n wimp."

7. The renowned South African scholar, Mamphela Ramphele (2002:14), explains how poor South African black women show the resilience and strength that have kept black families going for generations. Ironically this strength has kept them in abusive relationships because their men cannot cope with strong assertive women.

8. Ramphele (2002:14) sympathizes with the inability of men to deal with intimacy. "They feel trapped in a social dynamic that has failed to provide them with the tools to negotiate relationships with women that go beyond women meeting their physiological and emotional needs. Many have yet to be exposed to loving and caring relationships between men and women. How are they expected to manage their fears, insecurities and inadequacies without safe spaces? Is it surprising that many are resorting to the violence they have witnessed so often in their lives?

9. Moltmann (2000:273) is right in pointing out that the struggle for the liberation of both male and female is not only a socio-political matter. It touches upon the most intimate and, may I add, fragile, parts of our lives. 
that mainly consists of Roman Catholics and various forms of Protestants in various parts of the world.

The Dutch theologian Hendrikus Berkhof argues that Christian anthropology is strongly influenced by Greek philosophical thought. In classical Greek thought humans are portrayed, just like divine beings, as self-sufficient, independent spiritual beings. This view, according to Berkhof, has determined anthropological thinking in western societies until the present. The anthropology of German idealist philosophers like Kant and Hegel as well as the philosophies that stress the capacities of the human mind, emotions and motivations (will) are all variations of the classic Greek model of anthropology (Berkhof 1973:108-109). The dominant liberal or modernistic anthropologies that emphasize the rational capacities, autonomy and power ${ }^{10}$ of human beings therefore have their roots in this Greek model. The Christian understanding of God in western churches was for centuries determined by this Greek influence. God was understood as absolutely free, autonomous, self-sufficient, rational, powerful, impassionate and distant. This view of God strengthened the dominant anthropology of rationality, autonomy and power.

In the next section theological responses to this anthropology since the first part of the twentieth century is outlined. The subsequent development of a theological anthropology of relationality, dependence and vulnerability is sketched.

\section{Towards a Theological Anthropology of Dependence and Vulnerability}

a. The optimistic liberal anthropology of autonomy and power is being opposed by various important theologians of the twentieth and twenty-first centuries. ${ }^{11}$ In so-called nontheological circles this opposition is also evident. ${ }^{12}$ Berkhof may serve as a good example of a theologian who describes anthropology in terms of dependence and vulnerability.

b. Over against an anthropology of independence and power, Berkhof proposes an anthropology of relationality and dependence. He argues that human beings are called to live in relationships. We are called to be partners of fellow human beings and of God. We are simultaneously fellow-human beings and homo orans, i.e. worshippers of God. In living and historic relationships human beings are defined and developed. Therefore human identity is not a photo, but a film. Human beings have not yet arrived. We are still underway to whom we should be (1 John 3:2) (Berkhof 1973:112-115). To live as humans we need each other and we need God. To be human therefore is to live in relationships of dependence.

Various theologians base this dependence of human beings in the revelation of the triune God. The resurgence of Trinitarian thought in the twentieth century under

10. In two recent articles I have in more detail outlined the liberal anthropology of rationality, autonomy and power (see Koopman 2003a, 2003b)

11. In a recent study on the role of theological anthropology in economic life, Patricia Donohue-White, Stephen Grabill, Christophet Westley and Gloria Zuniga (2002:16-28) refer to the development of a relational anthropology based in Trinitarian thought that originated with Karl Barth in the first part of the twentieth century. Other theologians that they cite in this regard are the Protestants Emil Brunner and Reinhold Niebuhr and the Catholics Henri de Lubac and Karl Rahner.

12. The work of Alisdair MacIntyre in this regard is of great importance. He pleads that humans should not only be defined in terms of notions like rationality and independence. The feature of dependence is also central to humanity. He challenges our assumption of independence by showing how we enter into this world as dependent beings and how dependent we are in the closing stages of our lives. He also refers to other periods of dependence upon others during our lives, for example during sickness (MacIntyre 1999:1-3). 
influence of theologians such as the Protestant Karl Barth, the Roman Catholic Karl Rahner and the Orthodox Vladimir Lossky paved the way for a rethinking of anthropology from a Trinitarian perspective. Some would draw building blocks for theological anthropology from immanent Trinitarian thinking and others from economic Trinitarian thinking. Both Oduyoye and the North American theologian, Gary Deddo, base their anthropologies in Trinitarian thought.

Deddo, who is a Barthian scholar, wrote an article entitled "Persons in Racial Reconciliation: The Contributions of a Trinitarian Theological Anthropology" (1997). In typical Barthian fashion he states that the basic insights of a Trinitarian theological anthropology arise out of a consideration of the person and work of Christ. Jesus Christ reveals to us both who God is and who humankind is. In Christ we see the relational character of both God and human beings. "In Christ God is revealed to be the triune God, the God who exists from all eternity by virtue of the triune relations among Father, Son and Spirit. In Christ humanity is revealed also to exist by virtue of its relations, first with God and then with others and the rest of creation" (Deddo 1997:58). These relations, Deddo states, are not external or accidental to who we are. With an appeal to Barth as well as the Orthodox theologian, John Zizioulas, he states, "Relationship is essential and internal to divine and human existence. God would not be God were God not triune. If humanity did not exist in relationship, originally and continually with God, there would be no humanity. Humanity has its existence in and through personal relations" (Deddo 1997:59).

Deddo refers to the covenant to explain the nature of the relationships in which we live. These relationships are personal. They are covenantal relationships of holy love (Deddo 1997:60). This holy love is an essential feature of God's relationship to creation and of our relationship to one another. "Personal relationship is internal and eternal in God. Were God not Father and Son and Spirit in eternal communion of holy love, God would not be. The only God that is, is not a static, inert, mechanical oneness of stuff but a dynamic communion of the triune persons ... Ultimately our communion with one another is to reflect and bear witness not only to God's communion with us in Christ but also to the eternal triune communion of Father, Son and Spirit" (Deddo 1997:61). For Deddo (1997:69), being created in the image of God entails personally imaging in our human relationships the divine love imaged between Father and Son in the Spirit. Deddo understands human beings therefore as relational beings who are in need of God, each other and also the nonhuman part of creation. In these relationships the covenantal love of God is manifested.

Although Deddo does refer to the inner-Trinitarian relations he mainly works his Trinitarian anthropology out in terms of the revelation of the triune God, i.e. in terms of economic Trinitarian thinking. ${ }^{13}$ By contrast, Mercy Oduyoye focuses more on immanent Trinitarian thinking in the construction of her version of a Trinitarian anthropology. ${ }^{14}$ She suggests that a renewed investigation of what the early church tried

13. Berkhof's construction of a relational anthropology seems to be based in the category of economic Trinitarian thinking.

14. Miroslav Volf who also stresses the immanent Trinitarian approach, warns, in line with Nicholas Fedorov, against two dangers. We can forget that we are merely human and in a disregarding way imitate the triune God. Secondly, we can stress our human shortcoming to such an extent that we forget that our most basic human calling is to be like God. The important point is that we do have to recognize the resemblance between divine and human identities, but that we also acknowledge the broken, imperfect nature of the correspondences between creatures and the Creator. He consequently speaks of a social vision and not a social program that we can infer from Trinitarian thinking (Volf 1998:404-405). Robert Vosloo (2003:13-14) 
to say in the doctrine of the Trinity may yield models for building the human community, specifically male-female relations. This would entail relationships that do not rest on a hierarchy of being but on the diversity of gifts that operate in an integrative manner (Oduyoye 1982:207). She argues that to use relational language to speak of God provides us with integrated models of community. She pleads that God should not be viewed as a monad but as a 'centre of relations' in which Father, Son and Holy Spirit act and inter-act without subsuming or subordinating the Persons (Oduyoye 1982:207). ${ }^{15}$ This understanding of the divine life paves the way for describing our status as the image of God in terms of human relations of mutual interest, trust and responsibility. Trinitarian anthropology, according to Oduyoye (1982:203-206), would then involve that human beings are essentially relational beings. We live in relationships characterized by mutuality, reciprocity, interdependence and mutual responsibility.

c. The notion of dependency suggests vulnerability. Alisdair MacIntyre (1999:3) states that it is exactly because of our vulnerability that we are dependent beings. There are theologians who emphasize this notion of vulnerability and brokenness as constituent elements of human beings pertinently. Berkhof is well known for his portrayal of God's power as "weerlose overmacht" (vulnerable power - translation from Dutch NK). Thereby he implies that God is not the immovable static impassionate God of Greek philosophical thought. In the face of the immense suffering of human beings and the rest of creation God shows vulnerability. This vulnerability is best demonstrated in the suffering and death of Jesus Christ on Calvary. ${ }^{16}$ As those who are created in the image of God we also share in this vulnerability. Being the image of God does not only imply that we share in God's rationality, freedom and creativity, but that we also share in his quest for and even dependence upon relationship with others as well as in his vulnerability.

In the last part of this paper the implications of an anthropology of relationality, dependence and vulnerability for male and female relations are investigated.

\section{Relational Anthropology and Male and Female Relationships}

I believe an understanding of humankind in terms of relationality, dependence and vulnerability paves the way for overcoming the estrangements that both males and females suffer. Precisely through reconsidering what our humanity entails we are able to embark on the road of re-humanization. Endeavoring to determine the significance of this anthropology for male - female relations is not a straightforward task. Various arguments can be raised against such an anthropology. I would like to address three such objections. In

proposes the use of imagination (that would include images, metaphors, stories and aesthetics) as well as participation in the divine life to make the link between the triune life and the Christian moral life.

15. This plea is echoed and worked out by various theologians. Vosloo cites various recent Trinitarian studies in this regard. These studies recapture the medieval metaphor of 'divine dance' to describe the circumincessio (the movement amongst the persons, the permeation of one Person by the other, the co-inherence without confusion) in the Trinity. According to Elizabeth Johnson this divine dance implies a relationship among human beings where there is no room for subordination and marginalization. Catherine LaCugna also suggests that this metaphor of divine dancing opposes hierarchical thinking and paves the way for relationships of reciprocal giving and receiving (see Vosloo 2003:14-15).

16. Twentieth century theologians like the recently deceased Dorothy Sölle portrays this vulnerability of God in stronger terms. Though Sölle would accuse Moltmann of portraying the Father as a sadist with his formulation that Jesus' cry on the cross, 'why have Thou forsaken me,' constitutes a Deus contra Deum situation, they both proclaim patripassianism by suggesting that in the suffering of Jesus Christ the Father also suffered. 
addressing these objections, the significance of such an anthropology for male and female relationships will also become clear.

a. Firstly, does talk about dependence not strengthen the predominant view in patriarchal societies that women are dependent beings? Does this anthropology not only perpetuate the subjugation of women? Let me respond to this question by showing how liberating the notions of dependence and vulnerability can be for men. This anthropology teaches us men that our worth and strength do not reside in how much we can do and achieve, but in how much we give. Our worth, strength and dignity also reside in the fact that we receive. This anthropology teaches us that it is not only activity which determines our value but also our being, more pertinently our being together. My value as a person is not only determined by the notion of "I perform", but also by the notions of "I am" or even better "We are", "I belong", "I am being cared for", "I give and receive" as portrayed in the divine dance referred to earlier in this contribution. The vulnerability and dependence of myself and other males and females are not to be viewed as expressions of weakness, but as constituent elements of our humanity that serve as signposts to a full human life of dignity, wholeness and joy. Where men develop this understanding of humankind the door is opened for male and female relationships characterized by justice, peace and joy. ${ }^{17}$

This revaluation of vulnerability and dependence hopefully also explains why I opt for the term dependence rather than interdependence. The latter term may inhibit a positive view of the notion of dependence since it subtly carries the idea of independence with regards to many, or even most aspects and dependence with regard to a few other aspects. For us men who throughout our lives have heard that we are to be independent, the emphasis on our dependence might have liberating potential. For women who throughout their lives hear how dependent they are, the term interdependent that also suggests independence, may prove more liberating. Lasting joyous relationships between male and female, I believe, will be built where the recognition of dependence prevails amongst both males and females.

b. Secondly, what is the value of proposing this anthropology in African societies where an anthropology of relationality, mutuality and interdependence as expressed in the ubuntu notion did not bring about the liberation of African women? Does this sad phenomenon not perhaps indicate that the underlying problem is not an anthropological one and that the solution must be sought for somewhere else? I respond to this question by suggesting that the notion of ubuntu be revisited in order to spell out its potential for the re-humanization of males and females and our relationships in African and other societies. Most probably, such an investigation will indicate that there is nothing wrong with the ubuntu notion itself, but that we fail to practice what we preach. Maybe the retrieval of an anthropology of dependence and vulnerability will encourage us to discover the liberating implications of ubuntu for the women, and for the men, of Africa. This can be the case since this anthropology pertinently asks that women be full partners in this revaluation process - which was not the case previously.

c. Lastly, is the proclamation of an anthropology of dependence and vulnerability not dream-talk in societies where the predominant anthropology and ethos proclaim exactly the opposite? In adhering to an anthropology of dependence and vulnerability as the pathway to joyous male and female relationships, one should guard against over-

17. The Reformed philosopher Nicholas Wolterstorff (1983) describes a true human life as one where relationships are characterized by shalom that entails justice, peace and joy. 
optimism. In this regard Reinhold Niebuhr's realism should be kept in mind. He teaches that the best that we can work for is merely "approximate" victories. In the same vein Bonhoeffer reckons that human endeavors are at best only "humiliating solutions." This realism, however, should not inhibit us from striving to embody this dependence and vulnerability. In this regard Hauerwas' appeal that Christians do not become practical atheists needs to be taken seriously. In an article titled "Embarrassed by God's presence" he challenges us to make our sums, to do our planning, to set our aims, as if God is really present and as if He can really make a difference. So let us not ask this question on the plausibility and realizability of such an anthropology as if God cannot surprise us once again. And for Hauerwas, who is an ecclesial ethicist, this surprise occurs in the space of a community which does not strive to be relevant in this world, but to be faithful (Hauerwas 1983, Hauerwas \& Willimon 1989). I also believe that in and through his church God forms women and men to live in joyous relations that flow from lives where vulnerability and dependence are not viewed as vices but as virtues that serve as pathways to true womanhood and manhood, yes true humanhood.

\section{BIBLIOGRAPHY}

Berkhof, H 1973. Theologische Anthropologie. In: Nauta, LW et al (eds.): De veranderbaarheid van de mens, 106-120. Kampen: Kok.

Deddo, G 1997. Persons in Racial Reconciliation: The Contributions of a Trinitarian Theological Anthropology. In: Okholm, DL (ed.): The Gospel in black and white, 58-67. Downers Grove: Intervarsity Press.

Donahue-White, P et al 2002. Human Nature and the Discipline of Economics: Personalist Anthropology and Economic Methodology. Lanham, MD: Lexington Books.

Du Toit, L 2003. Rape Understood as Torture: What is the Responsibility of Men? In: Clowes, L \& Conradie, EM (eds.): Rape: Rethinking male responsibility, 36-66. Stellenbosch: EFSA.

Dvorkin, D 1976. Reflection: On Manhood. In: Jersild, P and Johnson, D (eds.): Moral issues and Christian responses, 187-191. New York: Holt, Rinehart and Winston.

Giddens, A 2002. The Transformation of Intimacy. Cambridge: Blackwell Publishers.

Hauerwas, S \& Willimon, W 1989. Resident Aliens. Life in the Christian colony. Nashville: Abingdon Press.

Hauerwas, S 1985. Embarrassed by God's presence. The Christian Century 102/4, 98-100.

Hauerwas, S 1983. The peaceable kingdom. A primer in Christian ethics. Notre Dame: University of Notre Dame Press.

Kombuis, K 2003. Rapport Perspektief 15 June, 2003, 18.

Koopman, NN 2003a. The dis-(differently-)abled and public morality. Scriptura 2003:1, $72-81$.

Koopman, NN 2003b. Theological Anthropology, ubuntu and Human Rights. In: Sporre, K \& Botman, HR (eds.): Building a Human Rights Culture: South African and Swedish Perspectives, 194-207. Falun: Dalarna University.

MacIntyre, A 1999. Dependent Rational Animals: Why Human Beings Need the Virtues. London: Duckworth.

Moltmann, J 2000. Experiences in Theology: Ways and Forms of Christian Theology. Minneapolis: Fortress Press. 
Oduyoye, MA 1982. Feminism: A Pre-Condition for a Christian Anthropology. African Theological Journal 3, 193-208.

Ramphele, M 2002. Steering by the Stars: Being Young in South Africa. Cape Town: Tafelberg Publishers.

Russell, L 1993. Church in the Round: Feminist Interpretation of the Church. Louisville, Kentucky: Westminster/John Knox Press

Stott, J 1990. Issues Facing Christians Today. London: Marshal Pickering.

Vogt, K 1985. 'Becoming Male': One Aspect of an Early Christian Anthropology. In: Schüssler Fiorenza et al (eds.): Women - invisible in theology and church. Edinburgh: T \& T Clark, 72-83.

Volf, M 1998. 'The Trinity is our Social Program': The doctrine of the Trinity and the shape of social engagement. Modern Theology 14/3, 403-423.

Vosloo, R 2003. Identity, Otherness and the Triune God: Theological Groundwork for a Christian Ethic of Hospitality. (forthcoming JTSA December 2004).

Wolterstorff, N 1983. When Justice and Peace Embrace. Grand Rapids: Eerdmans. 